\title{
Squamous Cell Breast Carcinoma, Large Cell Keratinizing Variant
}

National Cancer Institute

\section{Source}

National Cancer Institute. Squamous Cell Breast Carcinoma, Large Cell Keratinizing

Variant. NCI Thesaurus. Code C40357.

A squamous cell carcinoma that arises from the breast parenchyma and is characterized by the presence of large malignant cells that exhibit keratinization. 